Article

\title{
Visitors' Perception of Urban Nature Reserves in Poland
}

\author{
Maciej Wasilewski, Barbara Szulczewska *(D) and Renata Giedych $\mathbb{D}$ \\ Department of Landscape Architecture, Faculty of Horticulture, Biotechnology and Landscape Architecture, \\ Warsaw University of Life Sciences, 02-787 Warsaw, Poland \\ * Correspondence: barbara_szulczewska@sggw.pl; Tel.: +48-22-59-322-11
}

Received: 4 April 2019; Accepted: 5 July 2019; Published: 10 July 2019

\begin{abstract}
The importance of green areas for the well-being of city dwellers, upgrading their living conditions and health, has been discussed in a great number of publications. Relatively few studies have been devoted to urban natural protected areas. These areas are distinct due to the very often conflicting goals of their establishment and the social functions that they perform. Legal regulations concerning the establishment and management of these areas in force in Poland do not take into account the conditions mentioned above. Therefore, it seems justified to change the regulations and to establish a separate form of nature protection, particularly in the case of the nature reserves, as these most often appear in Polish cities and have the highest protection status. In order to support or refute this stipulation, the urban nature reserve (UNR) visitors were questioned (through a survey available online for six months in 2018). Eight-hundred and sixty-nine respondents took part in the survey. It revealed that most of the respondents perceived nature reserves located in cities as recreational areas; however, they were also aware of their multifunctional character. Such results support the conclusion that in order to effectively manage this type of area in cities, a concept of distinctive urban conservation areas should be developed.
\end{abstract}

Keywords: urban protected areas; nature-based recreation; nature reserves values; attitude to protected areas

\section{Introduction}

Urban Nature Reserves (UNR)-What Is Their Purpose in Cities?

The importance of green areas or in a broader sense nature for city dwellers has been discussed in a large number of publications. Its role in general well-being, and upgrading living (e.g., microclimate improvement, creating places for outdoor recreation) and health (e.g., recovery from stress) conditions has been described and documented by many authors [1-8]. The objects of research were usually parks and other formal green areas. In recent years, informal green open spaces have also become a subject of interest as potential areas for enhancing urban biodiversity-the concept of a "novel ecosystem" [9] and the possibility for the creation of a new type of green space [10-12].

At the turn of the 21st century, protected areas began to be perceived as an important element of ensuring proper living conditions in the city. At the same time, traditional nature conservation goals such as rarity and threat, sensitivity, naturalness, the degree of human interference, and the representativeness of ecological potential as well as the ability to regenerate, began to be perceived as insufficiently effective for preserving nature in the city [13-15]. More and more attention has been paid to the social function of naturally valuable areas within cities, including the benefits provided by protected areas [16-19]. Recognition of the need to combine the protective function with the recreational use of protected areas is also increasingly emerging [18,20-23]. 
Protected areas have their distinct specificity in cities. According to Trzyna [18], in comparison to their traditional counterparts, urban protected areas receive a large number of visitors (including everyday ones) and relate to numerous actors. This specificity is very often based on conflicting goals of their functioning/preserving. On the one hand, they are created in order to protect the survived elements of wild nature or the remnants of the natural or sometimes cultural landscape. On the other hand, they are treated by the city dwellers as recreational areas that are usually lacking in cities. The balance between "social" and "nature conservation" objectives for setting up urban nature reserves (UNRs) should be considered as one of the crucial concerns of their future. The concept of a UNR differs from country to country because it depends on the definition, tradition, legal regulations, and also social perceptions of this kind of green open space. However, regardless of the motives for establishing and managing them, recent studies show that UNRs are becoming increasingly popular for recreational activities [24-26].

Research conducted by Borgström, Lindborg and Elmqvist [27] related to the objectives of establishing nature reserves in southern Sweden revealed the specificity of Swedish UNRs, which consists of (1) the different composition of objectives used in UNRs compared to rural ones and (2) focusing on delivering "outdoor recreation" as the aim of UNRs, rather than "preserving environments", which is more common in rural reserves. Girault [28] discussed the specificity of UNRs in Helsinki from the point of view of the balance between "naturalness and urbanity". Taking into account the characteristics of the reserves, a relatively small area (more than half cover less than two hectares), in many cases privately owned and scattered around the city, in many cases consisting of rocky islets that cannot be reached by public transportation, she argues that these reserves cannot be considered urban protected areas. Thus, she supports the policy of creating a coherent network of nature areas, whether protected or not, as being more important than the strength of the protection given to a specific area of a city.

In Poland, research on the present situation and the problems associated with protected areas in cities was performed by Giedych [29]. Based on the analysis of 229 areas that represent different protection forms, she stated:

- there is no legal distinction between urban and rural protected areas, so the same principles apply to their appointment and protection;

- $\quad$ specificity of urban protected areas;

- conservation goals assigned to particular nature conservation categories often do not take into account the context of their location within a city's limits;

- current legal regulations do not allow full individualization of the scope of regulations for individual protected areas, forcing a rigid catalog of restrictions set out in the Nature Conservation Act.

These general observations also refer to the situation of UNRs in Polish cities. However, studies devoted to this form of protection are not very numerous. Most of them concentrate on single case studies or studies dedicated to a particular city. Two Warsaw UNRs (remnants of forests, situated in residential districts, with good access to public transportation: Kabacki Forest and Bielanski Forest) were studied from the point of view of their recreational use. Górecka [30], taking into account the results of a survey with 500 users of Bielański Forest, stated that the most common recreational activities were biking, running, and walking. The most frequently reported defects in terms of recreational equipment included lack of camping places, lack of parking lots, or an insufficient number of clearings for rest. However, in the case of Kabacki Forest, Prószyńska-Bordas, Fijałkowska and Poświata [31] stated that the recreational equipment satisfied the users. According to a social survey, only sanitary and hygienic issues needed to be solved in order to prevent the devastation of the forest. Kabacki Forest was also surveyed by Malinowska and Szumacher [32], this time from diverse points of view: awareness of threats to the natural environment caused by recreational pressure; readiness to abandon the preferred forms of rest and recreation in order to increase the effectiveness of the protection of nature; 
the possibility of resolving conflicts between recreational use of the reserve and nature protection needs; natural values and their perception; and preferred forms of recreational behavior. The survey revealed that Kabacki Forest nature reserve is perceived primarily as a recreational area for residents of nearby neighborhoods. Only a few people underlined its dominant protective function. The dominant forms of recreation in the forest were: playing sports, meeting new people, participating in social gatherings, escaping noise and pollution, and improving health and physical condition. The need for contact with the natural landscape and enjoying nature was only occasionally mentioned.

The first research covering UNRs (157 in total) in all Polish cities was devoted to the reasons why they were established [33]. This study revealed that in the case of UNRs, protection objectives are often not precisely formulated, possibly due to management problems regarding the reserves' recreational use. It should also be noted that recreation is not considered to be a justification for setting up nature reserves. Only protection objectives are taken into account. However, in theory, the current legal regulations allow for rules regarding recreational use to be established and the necessary facilities to be set up, but in practice, this issue seems to have been overlooked in many cases.

According to Polish law, nature reserves include areas that play a key role in preserving natural or slightly changed ecosystems, refuges, and natural habitats of plants, animals and fungi, as well as elements of inanimate nature, which are distinguished by special natural, scientific, cultural or landscape values. Polish nature reserves are classified in the IV category by the IUCN and usually reflect the primary objective of this category: "to maintain, conserve and restore habitats and species" [34]. Less often they meet the other objectives, in particular, to provide urban residents with contact with nature. This is mainly due to the fact that, in pursuance of the Nature Conservation Act of 2004 , all activities that are not related to the nature conservation objectives are prohibited as a rule. Using nature reserves for recreational purposes requires the consent of the Regional Directorates for Environmental Protection and can be specified in regional ordinances and/or regulations included in management plans.

Therefore, besides the well-known problem of urban pressure on protected areas (intensification of development in their vicinity, landscape fragmentation, isolation), in the case of Polish UNRs, their use for outdoor recreation generates management and protection problems. These problems arise because in many cases UNRs are not properly adapted to this kind of use but at the same time they are used, sometimes in an intensive manner, for different forms of recreation. One can ask the question: what are UNRs for? Should they support green areas in enabling conditions for city dwellers' recreation or should they protect the natural and sometimes cultural heritage of the city? Of course, in practice, such a dilemma can be considered as too austere. It may depend on the location of the reserve, its natural values, the occurrence of recreational areas in its vicinity, the kind of recreational use and so on. However, there is still the problem that UNRs are not just another kind of green open space in a city. Different measures can be applied in order to solve this problem. Malinowska and Szumacher [32] suggest limiting accessibility (extreme solution), or rigorous observance and enforcement of established protection rules. Giedych [29] suggests changes in legal regulations to integrate the multifarious functions of urban protected areas and to introduce a more innovative model of nature conservation in cities.

Taking into account the suggestions mentioned above, and in order to support the necessity of broadening the goals of UNR establishment, a survey focusing on the problem of the social perception and use of nature reserves located in Polish cities was carried out. Particular attention was paid to revealing whether the reasons for visiting the reserves were mostly recreational or rather founded on the need for contact with nature and specific natural and/or cultural values, predicted to be dominant in these areas. A recreational function, emphasized by users, would indicate the need for change. 


\section{Materials and Methods}

\subsection{UNRs in Poland}

As mentioned in the Introduction, according to the Nature Conservation Act of 2004, nature reserves in Poland are established in order to protect natural values, mainly for scientific and educational reasons. That is normally included in regional ordinances issued by the Regional Directorates for Environmental Protection while an individual nature reserve is being established. Very rarely, the other reasons are also mentioned in these documents, e.g., social, cultural or historical values.

There are, in total, 1498 nature reserves in Poland, of which 157 are situated in cities. However, in some cases, a part or even most of their areas are outside city boundaries. In the study, we decided to focus on 111 nature reserves (about 7.5\% of all the Polish nature reserves) that are located entirely within city borders. This number refers to 75 Polish cities (out of 940 cities in Poland, thus constituting about $8 \%$ ). Warsaw is a leading example, with nine nature reserves entirely situated within its city limits. It is followed by Cracow and Kielce (5), Gdańsk (4), Gdynia and Podkowa Leśna (3). A great majority of the remaining 69 cities have one nature reserve in their boundaries.

Many UNRs are located in the immediate vicinity of residential areas (e.g., Czerniakowskie Lake in Warsaw, Xerothermic Grasslands in Gorzów Wielkopolski, Zwierzyniecki Forest in Bialystok), or within municipal forests (e.g., Maiden Rocks in Cracow, Lagiewnicki Forest in Lodz, Springs in the Eva Valley in Gdansk). It makes them as often used as another urban green area.

\subsection{Questionnaire}

In order to identify social perceptions of the functions of UNRs located in Polish cities and the ways in which they are used by people, an online survey was carried out.

The assumption was made that visitors' perception and use of UNRs will depend mostly on their age (younger people are more interested in using nature reserves for recreation purposes), their education level (better educated people are more aware of the function of nature reserves and the resulting restrictions in their use) and the city size (dwellers of bigger cities are more frequent users of nature reserves in order to be in contact with nature).

A survey was prepared with the use of the webankieta platform (www.webankieta.pl) and it was available online from January to June 2018. It could be easily completed online on computers and on mobile electronic devices.

The respondents were asked to provide information about UNRs that they know or they have ever visited. They were provided with a map that presented all the cities having UNRs within their boundaries (one or more out of 111 UNRs mentioned above (see Figure 1)). The map was followed by a list containing names of nature reserves, divided according to the cities. We added the information that the survey was addressed to people who had visited at least once in their life-UNRs (one or several) from the presented list. Before commencing the survey, the participants could read a legal definition of nature reserves that was also given as an introduction to the questionnaire. 


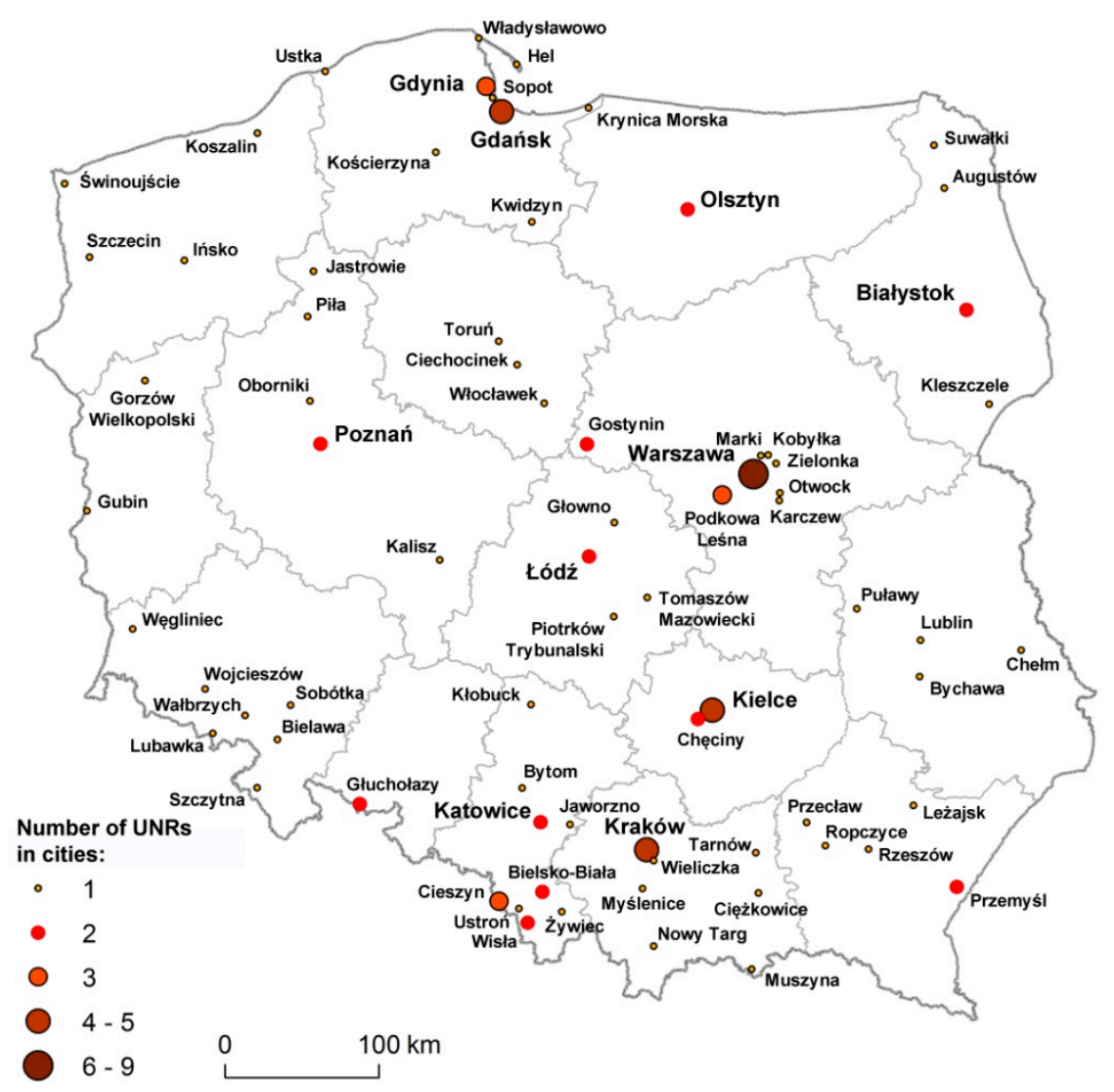

Figure 1. Number of urban nature reserves (UNRs) located in Polish cities and towns.

We specified four categories for the participants' ages: 19-25, 26-40, 41-60, $>60$, three categories for city size: $<100,000,100,000-500,000,>500,000$ (inhabitants) and three categories for education: secondary education, in the course of studying and higher education.

It was expected that most of the respondents would be city dwellers. In order to obtain a high number of responses, different methods were used to spread the information about the survey on the Internet. A key source of respondents was social media-Facebook. For this purpose, we used the snowball sampling technique [35]. A link to the survey was placed on the authors' profiles and was then multiplied by a circle of friends, relatives and other people. Moreover, we placed the link on many users' or institutions' Facebook profiles, which were then shared further with other Facebook users. Besides that, we used an advertising campaign on Facebook to reach more potential nature reserve users. The campaign was addressed to city dwellers (over 18 years old) living in the cities mentioned above. Apart from the snowball sampling technique we also distributed the questionnaire by placing the web link to the questionnaire on many public Internet forums devoted to groups of people with special interests and hobbies such as bikers, runners, climbers, photographers, bird watchers, and people enjoying nature in general. Similarly, the survey was distributed on several Internet forums for adults and seniors. Furthermore, emails with the web link to the questionnaire were sent to several institutions (e.g., universities, NGOs dealing with nature protection, ecology and tourism, tourist institutions, urban movements) and representatives of local initiatives.

The questionnaire was divided into three parts according to the following issues:

(1) Perceptions and expectations: how do people perceive UNRs? We asked UNR users to identify the values of those areas that are particularly important for them. We also gathered their opinions on whether they expected UNRs to offer more social/ recreational activities than they currently do. 
(2) Motivations: what are the reasons and incentives for visiting UNRs? To find this out we asked the participants: (a) where they learned about visiting UNRs, (b) why they visited UNRs and (c) whether they visited UNRs alone or accompanied by other people?

(3) Observations: to what extent are UNRs social places? Participants of the survey were asked to identify the social activities observed among other UNR users.

The obtained data were analyzed using Statistica 13 software. We interpreted the received answers with reference to age categories and city size. According to Malinowska and Szumacher [32], the gender category is not decisive in this kind of research. The results were analyzed mainly based on the percentage of indicated answers received in relation to the total number of respondents in each category. To verify potential correlations and trends with background factors (age, city size, education) we used Pearson's correlation coefficient.

\section{Results}

\subsection{Profiles of the Respondents}

A total number of 943 online surveys were obtained. From these, we used 869 questionnaires since the remaining 74 were incomplete. The largest group of respondents belongs to the age category $26-40(n=344)$, followed by $19-25(n=260)$ and $41-60(n=204)$. The smallest number of online surveys was received from the group $>60-n=61$ (Table 1). Almost half of the respondents $(47.5 \%$, $\mathrm{n}=431$ ) live in large cities with populations over 500,000 . We gathered fewer data from users of UNRs coming from smaller cities and towns (Table 1). Most people who took part in the survey had higher education ( $n=641,73.8 \%) ; 10.2 \%$ of respondents had secondary education $(n=89)$ and the remaining $16 \%(n=139)$ were still studying.

Table 1. Profile of surveyed UNRs users $(n=869)$.

\begin{tabular}{ccccc}
\hline City Size: & $<\mathbf{1 0 0 , 0 0 0}$ & $\mathbf{1 0 0 , 0 0 0 - 5 0 0 , 0 0 0}$ & $\mathbf{> 5 0 0 , 0 0 0}$ & Total Number \\
\hline Age category: & & & & \\
$\mathbf{1 9 - 2 5}$ & 101 & 35 & 124 & 260 \\
$\mathbf{2 6 - 4 0}$ & 77 & 89 & 178 & 344 \\
$\mathbf{4 1 - 6 0}$ & 41 & 66 & 97 & 204 \\
$\mathbf{> 6 0}$ & 14 & 15 & 32 & 61 \\
Total Number & $\mathbf{2 3 3}$ & $\mathbf{2 0 5}$ & $\mathbf{4 3 1}$ & $\mathbf{8 6 9}$ \\
\hline
\end{tabular}

\subsection{How do Visitors Perceive UNRs and What do They Expect from These Areas?}

Whereas legal reasons for the establishment of nature reserves are mainly scientific and educational, a large majority (79.5\%) of the surveyed people perceive UNRs not only as areas with high natural values but also as places important for recreation and leisure (Table 2). The respondents indicate also the importance of their educational values (56.6\%). A significant share of the questionnaire participants stated that cultural aspects (34.6\%) and social values (28.3\%), beyond natural values, are particularly important for them in the context of UNRs. It should be mentioned here that social aspects are more important for younger people (41.5\% respondents from the category 19-25) than for older visitors ( $26.5 \%, 17.2 \%$ and $19.7 \%$ of the surveyed $26-40,41-60$ and $>60$-year-olds respectively) (separate results for each age/city size category are not shown in the article; we mention in the paper only the most important results that indicate trends or correlations). Only 5.6\% of UNR users find these types of areas important solely due to their natural values. However, there is a distinct difference in opinions about this aspect between the oldest (>60: 13.1\%) and youngest respondents (19-25: 3.1\%).

Correlations between the age categories and (potential) values that UNRs constitute for the respondents are weak but statistically significant $(p$-value $<0.05)$ for social values $(-0.192)$ and leisure values (-0.109) —negative correlation—and for other values (0.128) and only natural values (0.118) - positive correlation (Table 2). This means that younger people more often recognize the 
social value of nature reserves in cities and use these areas for leisure and recreation more frequently than older people. A weak positive correlation for educational and scientific values may suggest that these aspects of UNRs are more recognized among older groups of respondents. A great educational potential seems to be therefore still not adequately used among younger people.

The results showed also some weak correlations between education as a background factor and educational and scientific values (positive correlation) and social values (negative correlation). This may indicate that highly educated people recognize the educational and scientific values of UNRs to a greater extent than less educated respondents who, on the other hand, perceive UNRs more frequently as social spaces.

Table 2. Results from the multiple-choice question "What aspects-beside nature values-are particularly important for you regarding urban nature reserves that you visited?" $(\mathrm{n}=869)$.

\begin{tabular}{|c|c|c|c|c|c|c|c|c|}
\hline \multicolumn{3}{|c|}{$\begin{array}{l}\text { What Aspects-Beside Nature Values-Are } \\
\text { Particularly Important for You Regarding } \\
\text { Urban Nature Reserves That You Visited? }\end{array}$} & \multicolumn{6}{|c|}{ Correlations with Background Factors } \\
\hline \multirow[b]{2}{*}{ Possible answers to choose: } & \multirow[b]{2}{*}{$\mathrm{n}$} & \multirow[b]{2}{*}{$\%$} & \multicolumn{2}{|c|}{ Age } & \multicolumn{2}{|c|}{ Education } & \multicolumn{2}{|c|}{ City size } \\
\hline & & & $\mathrm{R}$ & $p$-value & $\mathrm{R}$ & $p$-value & $\mathrm{R}$ & $p$-value \\
\hline Educational values & 492 & 56.6 & $0.095^{1}$ & $0.005^{2}$ & 0.139 & $<0.001$ & -0.037 & 0.279 \\
\hline Scientific values & 243 & 28.0 & 0.073 & 0.032 & 0.134 & $<0.001$ & -0.017 & 0.623 \\
\hline Cultural aspects & 301 & 34.6 & -0.094 & 0.006 & -0.015 & 0.651 & 0.024 & 0.488 \\
\hline History of the place & 162 & 18.6 & -0.040 & 0.234 & -0.018 & 0.607 & 0.009 & 0.782 \\
\hline $\begin{array}{l}\text { Recreational and leisure } \\
\text { values }\end{array}$ & 691 & 79.5 & -0.109 & 0.001 & -0.056 & 0.100 & 0.084 & 0.013 \\
\hline $\begin{array}{l}\text { Social values (e.g., meeting } \\
\text { spot, social activities) }\end{array}$ & 246 & 28.3 & -0.192 & $<0.001$ & -0.144 & $<0.001$ & 0.019 & 0.585 \\
\hline $\begin{array}{c}\text { Other values, not listed } \\
\text { above }\end{array}$ & 11 & 1.3 & 0.128 & $<0.001$ & $<0.001$ & 0.995 & 0.023 & 0.499 \\
\hline $\begin{array}{l}\text { Only natural values are } \\
\text { important for me }\end{array}$ & 49 & 5.6 & 0.118 & $<0.001$ & 0.082 & 0.015 & -0.034 & 0.313 \\
\hline
\end{tabular}

${ }^{1}$ More important correlations are marked in bold; ${ }^{2}$ Significant at $p<0.05$.

As the results show, it is not clear whether UNRs should offer more leisure recreational and social activities than is currently the case. Although $43.4 \%$ of those surveyed stated that they did not expect a broader offer from UNRs, a significant number of the respondents (34.6\%) had a different view on this matter. The remaining $22.0 \%$ did not have any clear opinion on this point (Table 3 ). The results revealed that although UNRs are already perceived as multifunctional places, additional social and recreational values are expected by many users.

Table 3. Results from the question "Should urban nature reserves offer a broader scope of social and recreational activities?" ( $\mathrm{n}=869)$.

\begin{tabular}{ccc}
\hline \multicolumn{2}{c}{ Should Urban Nature Reserves Offer a Broader Scope of Social and Recreational Activities? } \\
\hline Possible answers to choose: & $\mathrm{n}$ & $\%$ \\
\hline Yes & 301 & 34.6 \\
I do not know & 191 & 22.0 \\
No & 377 & 43.4 \\
\hline
\end{tabular}

What is interesting is that there is a negative weak correlation between the age $(-0.216)$ and education (-0.114) categories and the users' expectations related to UNR functions (Table 4). This association can be seen also when analyzing the answers obtained for each category separately. $46.2 \%$ of the respondents 19-25 years old stated that UNRs should offer a broader scope of social and recreational activities. The respondents from the older groups had a rather different opinion ("no"): $46.5 \%, 62.3 \%$ and $49.2 \%$ for the categories 26-40, 41-60 and $>60$, respectively. Among people with higher education, 
$48.2 \%$ answered "no" and 32.9\% "yes", whereas less educated respondents had a slightly different opinion: $41.6 \%$ answered "yes" and 32.6\% indicated "no" as an answer. The respondents who are still studying are also mostly in support of such changes (38.1\%). $28.1 \%$ of them answered "no". The statistical analyses of correlations, with the use of Pearson's coefficient, did not indicate any significant associations between the answer to this question and the city size.

Table 4. Correlations analyzed for the question "Should urban nature reserves offer a broader scope of social and recreational activities?" in relation to the age/education/city size categories.

\begin{tabular}{|c|c|c|c|c|c|c|}
\hline & \multicolumn{6}{|c|}{ Correlations with Background Factors } \\
\hline & \multicolumn{2}{|c|}{ Age } & \multicolumn{2}{|c|}{ Education } & \multicolumn{2}{|c|}{ City size } \\
\hline & $\mathrm{R}$ & $p$-value & $\mathrm{R}$ & $p$-value & $\mathrm{R}$ & $p$-value \\
\hline $\begin{array}{l}\text { Correlation between the } \\
\text { age/education/ city size } \\
\text { categories and } \\
\text { respondents' } \\
\text { expectations toward } \\
\text { UNRs }\end{array}$ & $-0.216^{1}$ & $<0.001^{2}$ & -0.114 & 0.001 & -0.032 & 0.349 \\
\hline
\end{tabular}

However, it should be mentioned here that whereas the respondents from medium-sized and large cities were rather skeptical about broadening UNRs' social and recreational offer (cities 100,000-500,000: yes $30.2 \%$, no $52.7 \%$; cities over 500,000 people: yes $34.8 \%$, no $41.5 \%$ ), a similar share of respondents from the smallest towns (less than 100,000 people) is either for or against ( yes $38.2 \%$, no $38.6 \%$ (the remaining percentage in each of the categories described refers to the answer "I do not know").

To sum up, users of UNRs perceive them as areas serving multiple functions, the most significant of which are recreational/leisure and educational. Only a small share of those surveyed associated UNRs solely with high nature values. The youngest UNR users perceived them mainly as social spaces for leisure and recreation, whereas the older respondents, to a greater extent than the younger, acknowledged their educational and nature values. Furthermore, younger respondents expect UNRs to offer more recreational and social activities, whereas the older participants of the survey were generally skeptical about that.

\subsection{What Are People's Motivations and Reasons for Visiting UNRs?}

Where do People Learn about UNRs?

About one-third of the respondents reported that they knew about UNRs from maps/city plans (37.6\%) or from childhood (33.3\%). The third most frequent answer (30.5\%) indicates that people learn about these places from other people. According to the results, an important source of information about UNRs are also teachers at schools or universities (26.0\%). The Internet, including official websites devoted to nature protection issues, plays a smaller role in popularizing knowledge about these protected areas (Table 5). Local authorities seem to have a marginal meaning-only $3.1 \%$ of respondents found out about UNRs from that source of information. It is worth mentioning that a significant share of the respondents (17.6\%) visited nature reserves in cities accidentally, without knowing about them before from other sources. Very often, such areas are located in close vicinity to people's living places and people use them, for example, for walking or walking the dog. A couple of survey participants learned about UNRs at work/workshops, from official boards found in these areas or from the information presented in this online survey (examples of own answers). 
Table 5. Results from the question "Where did you learn about the urban nature reserve/reserves that you visited?" ( $=869)$.

\begin{tabular}{|c|c|c|c|c|c|c|c|c|}
\hline \multicolumn{3}{|c|}{$\begin{array}{c}\text { Where Did You Learn about the Urban Nature } \\
\text { Reserve/Reserves That You Visited? }\end{array}$} & \multicolumn{6}{|c|}{ Correlations with Background Factors } \\
\hline \multirow[b]{2}{*}{ Possible answers to choose: } & \multirow[b]{2}{*}{$\mathrm{n}$} & \multirow[b]{2}{*}{$\%$} & \multicolumn{2}{|c|}{ Age } & \multicolumn{2}{|c|}{ Education } & \multicolumn{2}{|c|}{ City size } \\
\hline & & & $\mathrm{R}$ & $p$-value & $\mathrm{R}$ & $p$-value & $\mathrm{R}$ & $p$-value \\
\hline $\begin{array}{l}\text { I know this place/these places from } \\
\text { childhood }\end{array}$ & 289 & 33.3 & -0.024 & 0.474 & 0.002 & 0.963 & 0.008 & 0.818 \\
\hline $\begin{array}{l}\text { From a teacher at school/university } \\
\text { From other people: }\end{array}$ & 226 & 26.0 & $-0.246^{1}$ & $<0.001^{2}$ & 0.006 & 0.866 & -0.009 & 0.797 \\
\hline $\begin{array}{l}\text { family/friends/neighbors/ other city } \\
\text { dwellers, etc. }\end{array}$ & 265 & 30.5 & -0.087 & 0.011 & -0.062 & 0.069 & -0.012 & 0.732 \\
\hline From TV/the Internet/newspapers & 102 & 11.7 & 0.013 & 0.703 & 0.023 & 0.503 & 0.000 & 0.999 \\
\hline $\begin{array}{l}\text { From official Internet websites } \\
\text { devoted to nature protection }\end{array}$ & 149 & 17.1 & 0.094 & 0.006 & 0.103 & 0.002 & -0.013 & 0.706 \\
\hline From books/articles/booklets, etc. & 209 & 24.1 & 0.153 & $<0.001$ & 0.144 & $<0.001$ & 0.025 & 0.457 \\
\hline From maps/city plans & 327 & 37.6 & -0.021 & 0.542 & 0.087 & 0.010 & 0.062 & 0.067 \\
\hline From local authorities & 27 & 3.1 & -0.008 & 0.820 & 0.049 & 0.152 & -0.035 & 0.305 \\
\hline $\begin{array}{l}\text { I found this place/these places } \\
\text { accidentally }\end{array}$ & 153 & 17.6 & -0.100 & 0.003 & -0.124 & $<0.001$ & 0.045 & 0.189 \\
\hline In another way, not listed above & 40 & 4.6 & 0.105 & 0.001 & 0.063 & 0.063 & -0.012 & 0.719 \\
\hline
\end{tabular}

${ }^{1}$ More important correlations are marked in bold; ${ }^{2}$ Significant at $p<0.05$.

We found some weak correlations between respondents' age and the indicated answers. The younger the respondents are, the more significant-as a source of information-teachers are. Younger people, more often than older people, also learn about UNRs from other people (friends, family, etc.). On the other hand, there was a low positive correlation between age and the answer "from books/articles/ booklets, etc.") (Table 5). This can be confirmed with the number of responses obtained for the respective groups. Almost one-third of people aged 41-60 (31.9\%) and $>60(31.1 \%)$ indicated this answer, whereas in the category 19-25, the percentage was $13.8 \%$. Another weak correlations related to variable education. Older respondents, more often than younger visitors, found out about UNRs from books or articles, official websites or city plans. A city's size, according to the results, does not have any association with the way that people learn about UNRs.

Why do People Visit Urban Nature Reserves?

The obtained results show that people use UNRs mostly as places for leisure (walking 66.4\%) (Table 6). UNRs are also important places for relaxation and mental restoration, in the opinion of $59.5 \%$ of the respondents. A similar number of those surveyed indicated that they visited UNRs because of their passion for nature $(60.4 \%)$, but only for $2.1 \%$ of them $(n=18)$ was this the only reason. The study revealed that many city residents visited these types of areas for recreational purposes. Among such kinds of activities, cycling was the most popular $(29.9 \%)$, followed by jogging $(10.2 \%)$. When counting all recreational activities together, including extreme and less popular sport disciplines, such use of UNRs was indicated by $36.2 \%$ of the respondents. However, this is quite diversified among the analyzed age categories: $19-25-41.9 \%, 26-40-37.5 \%, 41-60-32.4 \%$ and $>60-18 \%$. Nature reserves in cities also play an important educational and scientific role. According to the answers obtained, such aspects were significant for $32.9 \%$ and $14.2 \%$, respectively. Almost one-fifth of respondents $(16.9 \%)$ visit UNRs as a place for meeting with friends and about one out of ten uses these areas to walk the dog (Table 6). UNRs are often located in the direct vicinity of or close to built-up areas. This is probably the reason why some people use these places as shortcuts in order to get to other places (7.8\%), e.g., to work. Some of those surveyed go to UNRs for picnicking or to barbeque ( $7.5 \%$ and $4.0 \%$, respectively). 
Table 6. Results from the question "Why do you visit urban nature reserves?" $(\mathrm{n}=869)$.

\begin{tabular}{|c|c|c|c|c|c|c|c|c|c|}
\hline \multicolumn{4}{|c|}{$\begin{array}{c}\text { Why Do You Visit Urban Nature } \\
\text { Reserves? }\end{array}$} & \multicolumn{6}{|c|}{ Correlations with Background Factors } \\
\hline \multirow[b]{2}{*}{$\begin{array}{l}\text { Possible answers to } \\
\text { choose: }\end{array}$} & \multirow[b]{2}{*}{$\mathrm{n}$} & \multirow[b]{2}{*}{$\%$} & \multirow{2}{*}{$\begin{array}{c}\begin{array}{c}\text { Selected } \\
\text { as the } \\
\text { only one }\end{array} \\
\%\end{array}$} & \multicolumn{2}{|c|}{ Age } & \multicolumn{2}{|c|}{ Education } & \multicolumn{2}{|c|}{ City size } \\
\hline & & & & $\mathrm{R}$ & $p$-value & $\mathrm{R}$ & $p$-value & $\mathrm{R}$ & $p$-value \\
\hline $\begin{array}{l}\text { Enjoying nature/ leisure in } \\
\text { a natural surrounding }\end{array}$ & 525 & 60.4 & 2.1 & 0.032 & 0.350 & 0.119 & $<0.001$ & -0.007 & 0.832 \\
\hline $\begin{array}{l}\text { Relaxation/mental } \\
\text { restoration }\end{array}$ & 517 & 59.5 & 1.6 & $-0.121^{1}$ & $<0.001^{2}$ & -0.016 & 0.645 & -0.001 & 0.989 \\
\hline Walking & 577 & 66.4 & 5.2 & -0.108 & 0.001 & -0.031 & 0.355 & 0.077 & 0.023 \\
\hline Walking the dog & 77 & 8.9 & 0.5 & -0.049 & 0.150 & -0.055 & 0.108 & 0.046 & 0.179 \\
\hline Jogging & 89 & 10.2 & & -0.092 & 0.007 & -0.038 & 0.269 & 0.051 & 0.132 \\
\hline Cycling & 260 & 29.9 & & -0.097 & 0.004 & -0.012 & 0.724 & 0.109 & 0.001 \\
\hline $\begin{array}{l}\text { For other } \\
\text { recreational/sport } \\
\text { activities }\end{array}$ & 22 & 2.5 & & 0.019 & 0.577 & -0.111 & 0.001 & 0.090 & 0.008 \\
\hline $\begin{array}{c}\text { Extreme sports } \\
\text { (motorbikes, quad bikes, } \\
\text { snowboard, etc.) }\end{array}$ & 13 & 1.5 & & -0.032 & 0.354 & -0.032 & 0.340 & -0.095 & 0.005 \\
\hline Picnicking & 65 & 7.5 & & -0.151 & $<0.001$ & -0.108 & 0.001 & 0.036 & 0.291 \\
\hline Barbeque/camping fire & 35 & 4.0 & & -0.154 & $<0.001$ & -0.126 & $<0.001$ & 0.039 & 0.254 \\
\hline $\begin{array}{c}\text { For other hobbies (e.g., } \\
\text { photography, } \\
\text { painting, etc.) }\end{array}$ & 139 & 16.0 & 0.3 & 0.061 & 0.073 & 0.008 & 0.811 & -0.023 & 0.499 \\
\hline $\begin{array}{l}\text { Place for a meeting with } \\
\text { friends }\end{array}$ & 147 & 16.9 & & -0.127 & $<0.001$ & -0.164 & $<0.001$ & 0.043 & 0.203 \\
\hline Educational reasons & 286 & 32.9 & 1.3 & 0.042 & 0.221 & 0.101 & 0.003 & -0.015 & 0.653 \\
\hline Scientific reasons & 123 & 14.2 & 0.9 & 0.076 & 0.025 & 0.114 & 0.001 & 0.012 & 0.724 \\
\hline $\begin{array}{l}\text { As a shortcut to get to } \\
\text { another place }\end{array}$ & 68 & 7.8 & 0.5 & 0.004 & 0.907 & -0.014 & 0.675 & 0.035 & 0.307 \\
\hline $\begin{array}{c}\text { Picking } \\
\text { mushrooms/berries }\end{array}$ & 31 & 3.6 & & -0.113 & 0.001 & -0.053 & 0.115 & -0.033 & 0.325 \\
\hline Fishing & 8 & 0.9 & & -0.062 & 0.069 & -0.020 & 0.561 & 0.028 & 0.408 \\
\hline Other reasons & 35 & 4.0 & 0.2 & 0.048 & 0.159 & 0.033 & 0.326 & 0.064 & 0.059 \\
\hline
\end{tabular}

${ }^{1}$ More important correlations are marked in bold; ${ }^{2}$ Significant at $p<0.05$.

A certain weak correlation can be noted between the aims of visiting UNRs and the background factors: age and education. In reference to the first one, a negative correlation $(-0.127)$ was calculated for the answer "place for a meeting with friends", which means that younger people use UNRs as places to meet with friends more often than older people. Picnicking and barbequing are also more popular among younger groups of respondents (Table 6). Other weak negative correlations are related to picking mushrooms/ berries, relaxing, walking, jogging and cycling. Respondents with a higher education visit UNRs more often for educational and scientific purposes, as well as for enjoying nature, whereas less educated people use them more frequently as a place for meeting with friends or for picnicking, barbequing and other various forms of recreation. As the statistical analyses revealed, city size has practically no significance for the aims of visiting UNRs. A positive weak correlation in relation to this factor was obtained for "cycling", which means that cycling in UNRs is slightly more popular among residents of more inhabited cities.

Visiting urban nature reserves: alone or in a group of people?

Most of those surveyed visited UNRs in the company of one person (38.7\%) (Table 7). It was the most frequent answer for three age categories (19-25, 26-40 and >60). A similar percentage of responses (35.0\%) refers to the answer "in a group of 2-4 people" and the respondents from the age category 41-60 indicated this answer the most frequently. Only one-fifth of the surveyed persons visit UNRs alone (20.9\%). It is worth mentioning here that this was the second most popular answer selected by the respondents over 60 years old (27.9\%). Visiting UNRs in larger groups of people is 
rather rare. Group visits of more than 10 people are most popular among the youngest respondents $(3.8 \%)$. It can be assumed that these are related mostly to educational walks, scientific research, or some recreational activities. In comparison to the other results, this happens distinctly less frequently.

Table 7. Results from the question "In whose company do you usually visit urban nature reserves?" $(\mathrm{n}=869)$.

\begin{tabular}{ccc}
\hline In Whose Company Do You Usually Visit Urban Nature Reserves? & & \\
\hline Possible answers to choose: & $\mathrm{n}$ & $\%$ \\
\hline Alone & 182 & 20.9 \\
In the company of one person & 336 & 38.7 \\
In a group of 2-4 people & 304 & 35.0 \\
In a group of 5-10 people & 28 & 3.2 \\
In a group of more than 10 people & 19 & 2.2 \\
\hline
\end{tabular}

According to the statistical analyses, there are no significant associations between respondents' age/education/city size and the number of people who accompany the respondents during their visits to UNRs. Only very weak linear correlations can be noted for the background factor city size (Table 8).

Table 8. Correlations analyzed for the question "In whose company do you usually visit urban nature reserves?" in relation to the age/education/city size categories.

\begin{tabular}{|c|c|c|c|c|c|c|}
\hline & \multicolumn{6}{|c|}{ Correlations with Background Factors } \\
\hline & \multicolumn{2}{|c|}{ Age } & \multicolumn{2}{|c|}{ Education } & \multicolumn{2}{|c|}{ City size } \\
\hline & $\mathrm{R}$ & $p$-value & $\mathrm{R}$ & $p$-value & $\mathrm{R}$ & $p$-value \\
\hline $\begin{array}{l}\text { Correlation between the } \\
\text { age/education/city size } \\
\text { categories and the number } \\
\text { of people that usually } \\
\text { accompany a respondent } \\
\text { during a visit to a UNR }\end{array}$ & -0.048 & 0.157 & -0.010 & 0.764 & $-0.079^{1}$ & $0.020^{2}$ \\
\hline
\end{tabular}

${ }^{1}$ More important correlations are marked in bold; ${ }^{2}$ Significant at $p<0.05$.

Visitors' motivations confirm that UNRs perform multiple functions for city dwellers. Leisure and recreational activities are the most common and they seem to play a bigger role than social, educational, or scientific values. Similar observations can be drawn from the way that people learn about UNRs. Diversified sources of information potentially increase the multifunctional use of these areas. Visiting UNRs in groups of 2-4 people, which is the most common according to the gathered data, may suggest their social and recreational use.

\subsection{Are UNRs Social Spaces? The Results from the Respondents' Observations}

The results gained from the respondents' observations of other users demonstrate that UNRs have significant social values for city inhabitants; $64.2 \%$ of those surveyed indicated "social meetings" as group activities observed in UNRs (Table 9). This most popular answer was followed by "educational events/workshops" (48.1\%), "leisure time in a family group" (43.6\%), "picnics" (40.2\%) and "barbeque, camping fire" (31.5\%). A significant number of respondents noticed various forms of outdoor games (29.3\%) in the visited UNR. In addition, playing children are often seen in UNRs (23.7\%). Other activities observed in UNRs and not listed in the questionnaire were, for example, group bicycle rides/races, marathons/organized runs and climbing. Only $7.7 \%$ of the respondents stated that they did not observe any group/ social activities in the visited UNR (Table 9). 
Table 9. Results from the question "Which of the group/ social activities listed below did you observe among other users of the visited urban nature reserves?" $(n=869)$.

$\begin{gathered}\text { Which of the Group/Social Activities Listed Below Did You Observe Among Other Users of the } \\
\text { Visited Urban Nature Reserves? }\end{gathered}$
\begin{tabular}{ccc} 
Possible answers to choose: & $\mathrm{n}$ & $\%$ \\
\hline Social meetings & 558 & 64.2 \\
Educational events/workshops & 418 & 48.1 \\
Picnics & 349 & 40.2 \\
Barbeque, camping fire & 274 & 31.5 \\
Thematic workshops/events & 112 & 12.9 \\
Historical events & 69 & 7.9 \\
Cultural events & 102 & 11.7 \\
Outdoor games (e.g., geocaching) & 255 & 29.3 \\
Organized activities of maintenance/cleaning up a nature reserve area & 156 & 18.0 \\
Playing kids & 206 & 23.7 \\
Leisure time in a family group & 379 & 43.6 \\
Other activities, not listed above & 40 & 4.6 \\
\hline
\end{tabular}

Social activities observed by almost every respondent confirm that UNRs serve as important social and multifunctional places for city dwellers, and the visitors use them in a similar way as other city green spaces.

\section{Discussion}

The results obtained from our survey enable us to characterize visitors' perceptions and actual use of UNRs in Poland. We have confirmed that at the moment users of Polish UNRs regard them-first of all-as recreational areas. They are aware of natural and other social values of these areas but they visit them mostly for leisure and recreation as other city green spaces. Similar conclusions are drawn from research on the biggest nature reserves in Helsinki: Viikii and Laajalahti nature reserves [28]. That might be considered as a quite normal and even required state of affairs in cities. Research conducted by Breuste [15] in Halle (Germany) revealed that the traditional targets of nature conservation in urban areas should be completed and/or replaced e.g., by usability, recreation, fostering contact with nature, enjoying the scenery, and well-being. However, in contrast to the situation of UNRs in e.g., Sweden [27], where delivering outdoor recreational possibilities is one of the objectives of establishing this form of nature conservation, in Poland, recreation is only allowed under certain circumstances and through some additional legal documents prepared individually for each nature reserve [33]. In addition, legal regulations regarding nature reserves are quite stringent due to the fact that, alongside national parks, they constitute the highest nature protection category. Hence, the possibilities of adaptation for recreational purposes are limited. At the same time, a frequent and intensive recreational use (e.g., cycling, jogging, playing) of some reserves would require the introduction of quite radical solutions. Many UNRs are not arranged and equipped in such a way as to serve leisure and recreational functions, which could result in the loss of nature values. This conflict cannot be solved easily in the contemporary Polish legal framework. It should be also underlined that the examples of Scandinavian nature reserves mostly refer to relatively large areas while most UNRs in Polish cities cover an area smaller than 50 ha (73\%) and 35\% of them (39 UNRs) are smaller than 10 ha.

In the context of the usual difficulties related to the change of legal regulations, the "soft instruments" of balancing recreation and experiencing nature in UNRs such as information and education should be considered more thoroughly. Recognizing the sources of information about UNRs (three most important: city maps $36 \%$, childhood $34 \%$, teachers $24 \%$ ) proves that only one-quarter of users have the chance to obtain relatively complete information, including the natural values and 
conservation reasons of the area. This lack of sensitivity to the needs of natural heritage preservation is confirmed by the observations of the recreational behavior of some UNR users.

The obtained Pearson correlations revealed interesting findings, referring to the importance of education and environmental awareness of nature protection purpose. Less educated people visit UNRs rather for recreation and social reasons (e.g., meetings) than to experience nature or for educational or scientific reasons. At the same time, they expect UNRs to be multifunctional and have a broader recreational and social offer. Highly educated people, on the other hand, value natural, scientific and educational aspects of UNRs to a greater extent. These respondents sought information about the visited UNRs from books and articles or at official Internet websites distinctly more frequently than less educated visitors. This shows the importance and influence of education and access to proper and available information on protected areas on the way they are used and perceived by visitors. These seem to be in conformity with the findings of Norman et al. [26], who argue that education and information are crucial for proper management of recreational activities in urban reserves.

Similar correlations were found in reference to age as a variable. Whereas younger visitors perceive and use UNRs mainly due to their recreation and social values, older respondents are more interested in natural, scientific and educational values, and they do not expect from UNRs any broader offer. Research conducted by the Scottish Natural Heritage on young adults and nature [36] shows a similar trend. The main motivations for visiting the natural environment among 16-24-year-olds are health and exercise, relaxation and spending time with family and friends. Comparable results we can find in the David Suzuki Foundation survey on youth engagement with nature and the outdoors [37]. Urban youth in Canada are more interested in active recreation in the bosom of nature than in learning about wildlife and ecosystems. Research conducted by Paul and Nagendra [38] shows that visitors over 55 years valued urban nature more for environmental benefits than the younger ones. The results may suggest that there is a growing generation of people that perceive and use UNRs practically in the same way as other green spaces in cities. Of course, it can be also the result of other factors such as rapid urbanization, an insufficient supply of green spaces in cities or a curriculum and educational methods at schools.

It might also be interesting to note that inhabitants of small towns, to a greater extent than dwellers of bigger cities, expect UNRs to offer more social and recreational activities than is currently the case. This can be explained by the smaller supply of attractive green open spaces or less knowledge about the objectives and backgrounds of UNRs in the current legal situation.

All aspects mentioned above should be taken into consideration and be addressed in management strategies of UNRs in order to integrate and balance nature and social values of these areas in the best possible ways. This would contribute to more efficient protection of UNRs. According to Ives [39], recognition of activities that people perform in nature reserves as well as understanding what people value and why can be helpful to manage human impacts on protected areas in cities, and ensure that urban nature can be more closely linked with "the life of the city". Alenezi [40] argues that due to many differences between urban and rural nature reserves they should be managed in different ways. He stresses that differences in perception and usage of nature reserves by urban and rural residents should be a key aspect in addressing the management goals.

Our survey was addressed to visitors of UNRs and this can constitute some limitations of the research since it cannot be seen as the opinion of city dwellers. As the questionnaire was available solely online, the group of respondents was limited to Internet users. Older people in Poland generally use electronic devices and the Internet less frequently than younger people. It can be assumed that they are not that active on social media and Internet forums. That is why it was slightly more difficult to reach this group.

In addition, opinions of tourists visiting nature reserves were not identified. Moreover, the survey was conducted in Polish language and this automatically excluded opinions of foreign visitors.

Furthermore, the simplicity of the survey, which aimed to obtain a high number of responses, does not allow us to see a more detailed association between the users and the individual UNRs. 
Answers may depend on various factors and characteristics of UNRs, such as location, public access, nature values, etc., which can influence people's motivation and their use of these areas. Such aspects undoubtedly need further research. The aim of this paper was, however, to encompass a broad general scale of the topic on a national level.

\section{Conclusions}

(1) The main findings of the survey proved that there is a fundamental discrepancy between:

- goals of setting up nature reserves and management practices resulting from acts of law being in force and

- actual visitors' perception of nature reserves located in cities and motivations for their use

(2) The discrepancy mentioned above poses a threat to achieving conservation goals since social functions (mostly recreational) are being developed in an uncontrolled and spontaneous manner.

(3) Since visitors perceive UNRs as multifunctional places where leisure, recreational and educational values have the greatest importance, there is a need to balance nature protection with users' demands.

These conclusions strongly support the idea of implementing a new category of nature conservation areas-Urban Nature Reserves. This protection category should;

- $\quad$ include clearly defined multifarious goals that are site-specific and respond to social needs

- $\quad$ be properly adjusted to multifunctional use;

- be managed in an adaptive way that would enable the inevitable conflicts between "man and nature" to be solved.

Of course, the presented idea requires further research on different management models, possible legal frameworks and setting up internal zoning and protection regimes.

Author Contributions: B.S. was the initiator of the paper, reviewed the literature, developed the methodology and co-wrote the article. M.W. developed the concept of the survey, analyzed the data, developed the results and co-wrote the article. R.G. reviewed the literature and co-wrote the article.

Funding: This research received no external funding.

Conflicts of Interest: The authors declare no conflict of interest.

\section{References}

1. Swanwick, C.; Dunnett, N.; Woolley, H. Nature, role and value of green space in towns and cities: An overview. Built Environ. 2003, 29, 94-106. [CrossRef]

2. Maas, J.; Verheij, R.A.; Groenewegen, P.P.; de Vries, S.; Spreeuwenberg, P. Green space, urbanity, and health: how strong is the relation? J. Epidemiol. Community Health 2006, 60, 587-592. Available online: https://jech.bmj.com/content/60/7/587 (accessed on 12 March 2019). [CrossRef]

3. Tzoulas, K.; Korpelab, K.; Vennc, S.; Yli-Pelkonenc, V.; Kaźmierczak, A.; Niemela, J.; James, P. Promoting ecosystem and human health in urban areas using Green Infrastructure: A literature review. Landsc. Urban Plan. 2007, 81, 167-178. [CrossRef]

4. Matsuoka, R.H.; Kaplan, R. People's needs in the urban landscape: Analysis of landscape and urban planning contributions. Landsc. Urban Plan. 2008, 84, 7-19. [CrossRef]

5. D'Souza, R.; Nagendra, H. Changes in public commons as a consequence of urbanization: the Agara lake in Bangalore, India. Environ. Manag. 2011, 47, 840-850. [CrossRef] [PubMed]

6. Eder, R.; Arnberger, A. The influence of place attachment and experience use history on perceived depreciative visitor behavior and crowding in an urban national park. Environ. Manag. 2012, 50, 566-580. [CrossRef] [PubMed]

7. Shwartz, A.; Cosquer, A.; Jaillon, A.; Piron, A.; Julliard, R.; Raymond, R.; Simon, L.; Prévot-Julliard, A.C. Urban biodiversity, city-dwellers and conservation: How does an outdoor activity day affect the human-nature relationship? PLoS ONE 2012, 7, e38642. [CrossRef] [PubMed] 
8. Budruk, M.; Lee, W. Importance of managing for personal benefits, hedonic and utilitarian motivations, and place attachment at an urban natural setting. Environ. Manag. 2016, 58, 504-517. [CrossRef]

9. Kowarik, I. Novel urban ecosystem, biodiversity and conservation. Environ. Pollut. 2011, 159, $1974-1983$. [CrossRef] [PubMed]

10. France, R.L. Environmental Restoration and Design for Recreation and Tourism; CRC Press: Boca Raton, FL, USA; Taylor and Francis: New York, NY, USA; London, UK, 2012.

11. Hopkins, J.C.; Neal, P. The Making of the Queen Elisabeth Olympic Park; John Wiley \& Sons: Hoboken, NJ, USA, 2013.

12. Elmqvist, T.; Setälä, H.; Handel, S.N.; van der Ploeg, S.; Aronson, J.; Blignaut, J.N.; Gómez-Baggethun, E.; Nowak, D.J.; Kronenberg, J.; De Groot, R. Benefits of restoring ecosystem services in urban areas. Curr. Opin. Environ. Sustain. 2015, 14, 101-108. [CrossRef]

13. Harrison, C.; Davies, G. Conserving biodiversity that matters: Practitioners' perspectives on brownfield development and urban nature conservation in London. J. Environ. Manag. 2002, 65, 95-108. [CrossRef]

14. Miller, J.R.; Hobbs, R.J. Conservation where people live and work. Conserv. Biol. 2002, 16, 330-337. [CrossRef]

15. Breuste, J. Decision making, planning and design for the conservation of indigenous vegetation within urban development. Landsc. Urban Plan. 2004, 68, 439-452. [CrossRef]

16. Yli-Pelkonen, V.; Niemela, J. Linking ecological and social systems in cities: Urban planning in Finland as a case. Biodivers. Conserv. 2005, 14, 1947-1967. [CrossRef]

17. Niemela, J.; Saarela, S.R.; Soderman, T.; Kopperoinen, L.; Yli-Pelkonen, V.; Vare, S.; Kotze, D.J. Using the ecosystem services approach for better planning and conservation of urban green spaces: A Finland case study. Biodivers. Conserv. 2010, 19, 3225-3243. [CrossRef]

18. Trzyna, T. Urban Protected Areas: Profiles and Best Practice Guidelines. Best Practice Protected Area Guidelines Series 22; IUCN: Gland, Switzerland, 2014.

19. Castro, A.J.; Martín-Lopez, B.; Lopez, E.; Plieninger, T.; Alcaraz-Segura, D.; Vaughn, C.C.; Cabello, J. Do protected areas networks ensure the supply of ecosystem services? Spatial patterns of two nature reserve systems in semi-arid Spain. Appl. Geogr. 2015, 60,1-9. [CrossRef]

20. Ruliffson, J.A.; Haight, R.G.; Gobster, P.H.; Homans, F.R. Metropolitan natural area protection to maximize public access and species representation. Environ. Sci. Policy 2003, 6, 291-299. [CrossRef]

21. Jim, C.Y. Green-space preservation and allocation for sustainable greening of compact cities. Cities 2004, 21, 311-320. [CrossRef]

22. Sandstrom, U.G.; Angelstam, P.; Khakee, A. Urban comprehensive planning-Identifying barriers for the maintenance of functional habitat networks. Landsc. Urban Plan. 2006, 75, 43-57. [CrossRef]

23. Worboys, G.; Lockwood, M.; Kothari, A.; Feary, S.; Pulsford, I. Protected Areas. Governance and Management; ANU Press: Canberra, Australia, 2015.

24. Gundersen, V.; Tangeland, T.; Kaltenborn, B.P. Planning for recreation along the opportunity spectrum: The case of Oslo, Norway. Urban For. Urban Green. 2015, 14, 2010-2017. [CrossRef]

25. Greer, K.; Day, K.; McCutcheon, S. Efficacy and perception of trail use enforcement in an urban natural reserve in San Diego, California. J. Outdoor Recreat. Tour. 2017, 18, 56-64. [CrossRef]

26. Norman, P.; Pickering, C.M.; Castley, G. What can volunteered geographic information tell us about the different ways mountain bikers, runners and walkers use urban reserves? Landsc. Urban Plan. 2019, 185, 180-190. [CrossRef]

27. Borgström, S.; Lindborgb, R.; Elmqvist, T. Nature conservation for what? Analyses of urban and rural nature reserves in southern Sweden 1909-2006. Landsc. Urban Plan. 2013, 117, 66-80. [CrossRef]

28. Girault, C. Between naturalness and urbanity, how are protected areas integrated into cities? The case of Helsinki (Finland). J. Urban Res. 2017, 16. Available online: https://journals.openedition.org/articulo/3270 (accessed on 1 March 2019).

29. Giedych, R. Ochrona przyrody w polityce przestrzennej miast [Nature Protection in the City Spatial Policy]; Komitet Przestrzennego Zagospodarowania Kraju PAN: Warszawa, Polska, 2018; Volume 252. (in Polish)

30. Górecka, A. Funkcja rekreacyjna warszawskiego Lasu Bielańskiego [Recreational function of Warsaw's Bielanski Forest]. Studia Mater. Cent. Edukac. Przyr. Leśnej 2009, 11, 172-179. 
31. Prószyńska-Bordas, H.; Fijałkowska, A.; Poświata, M. Cechy społeczne, zachowania i motywacje osób odwiedzających Rezerwat Las Kabacki w Warszawie oraz ich opinie o przygotowaniu obszaru do rekreacji (in Polish) [Social features, behaviour and motivations of visitors to the forest reserve Wood Kabacki in Warsaw and their opinions on the preparation of the area for recreation]. Tur. Rekreac. 2010, 6, 85-98.

32. Malinowska, E.; Szumacher, I. Survey of recreational use of the Las Kabacki, forest nature reserve in Warsaw (Poland). Misc. Geogr. Reg. Stud. Dev. 2013, 17, 12-18. [CrossRef]

33. Wasilewski, M.; Szulczewska, B. Protection objectives in Polish urban nature reserves as a challenge for their management. Maz. Studia Reg. 2017, 22, 15-28. [CrossRef]

34. Dudley, N. Guidelines for Applying Protected Area Management Categories; IUCN: Gland, Switzerland, 2008.

35. Biernacki, P.; Waldorf, D. Snowball sampling: problems and techniques of chain referral sampling. Sociol. Methods Res. 1981, 10, 141-163. [CrossRef]

36. Scottish Natural Heritage. Young Adults and Nature: Key Research Findings. 2019. Available online: https:/www.nature.scot/sites/default/files/2019-05/Scottish\%20Nature\%20Omnibus\%20\%20summaries\%20-\%20Young\%20adults\%20and\%20nature_0.pdf (accessed on 31 May 2019).

37. The David Suzuki Foundation. Youth Engagement with Nature and the Outdoors. A Summary of Survey Findings. 2012. Available online: https://davidsuzuki.org/wp-content/uploads/2012/09/youth-engagementnature-outdoors.pdf (accessed on 31 May 2019).

38. Paul, S.; Nagendra, H. Factors Influencing Perceptions and Use of Urban Nature: Surveys of Park Visitors in Delhi. Land 2017, 6, 27. [CrossRef]

39. Ives, C.A. Values-Based Approach to Urban Nature Research and Practice. Smart Cities Dive. 2014. Available online: https://www.smartcitiesdive.com/ex/sustainablecitiescollective/values-based-approach-u rban-nature-research-and-practice/244696/ (accessed on 31 May 2019).

40. Alenezi, M.S. Geographic Assessment of the Perception of Nature Reserves and National Parks in Kuwait. Theses and Dissertations. University of Arkansas, 2014. Available online: https://scholarworks.uark.edu/cgi/ viewcontent.cgi? referer=https://www.google.com/\&httpsredir=1\&article=3558\&context=etd (accessed on 31 May 2019).

(C) 2019 by the authors. Licensee MDPI, Basel, Switzerland. This article is an open access article distributed under the terms and conditions of the Creative Commons Attribution (CC BY) license (http://creativecommons.org/licenses/by/4.0/). 